\title{
TOTAL BAKTERI ASAM LAKTAT (BAL), AKTIVITAS ANTIOKSIDAN, DAN PENERIMAAN YOGHURT HERBAL SINBIOTIK DENGAN PENAMBAHAN EKSTRAK KAYU MANIS (CINNAMOMUM BURMANII)
}

\author{
Gita Ramayani $^{1}$, Ninik Rustanti ${ }^{1}$, Deny Yudi Fitranti ${ }^{1}$ \\ ${ }^{1}$ Departemen Ilmu Gizi, Fakultas Kedokteran, Universitas Diponegoro \\ Jln. Prof. H. Soedarto, SH., Semarang, Telp (024) 76402881, Email : gizifk@ undip.ac.id
}

\begin{abstract}
Background : Antioxidant diet may decrease the occurrence of metabolic syndrome. Formulated yogurt with inulin and carrageenan extract may be a product innovation for metabolic syndrome patient.

Objective : To analyze total lactic acid bacteria (LAB), antioxidant activity, and acceptability of symbiotic herbal yogurt with cinnamon extract.

Method : This research was true experimental with completely randomized single factor, namely the addition 0\% (control); $0.1 \%$; $0.3 \%$; and $0.5 \%$ of cinnamon extract to symbiotic herbal yogurt. Total lactic bacteria was counted using Total Plate Count method, while the antioxidant activity was tested using DPPH. Acceptance test used a hedonic test method.

Result : There was no effect of adding cinnamon extract with a variety of treatments to total lactic acid bacteria. Yogurt with 0,5\% cinnamon extract had the highest antioxidant activity of 77,33\%. There was different in aroma, flavor and texture between control and treatment group but wasn't in color acceptance.

Conclusion : Symbiotic herbal yogurt added 0,3\% cinnamon extract was the best formulation which had total lactic acid bacteria $\geq 10^{7} \mathrm{CFU} / \mathrm{ml}$ according to SNI, quite high antioxidant activity $56.67 \%$, and favored enough on acceptance.
\end{abstract}

Keywords : herbal yogurt, inulin, carrageenan, cinnamon bark extract, antioxidant activity, total lactic acid bacteria

\section{ABSTRAK}

Latar Belakang : Diet antioksidan dapat menurunkan kejadian sindrom metabolik. Formulasi yoghurt tersebut yang ditambahkan inulin dan karagenan dapat menjadi inovasi produk untuk pasien sindrom metabolik.

Tujuan : Menganalisis total bakteri asam laktat (BAL), aktivitas antioksidan, dan penerimaan yoghurt herbal sinbiotik dengan penambahan ekstrak kayu manis.

Metode : Penelitian ini merupakan true experimental dengan rancangan acak lengkap satu faktor, yaitu penambahan ekstrak kayu manis 0\% (kontrol); 0,1\%; 0,3\%; dan 0,5\% pada yoghurt herbal sinbiotik. Total bakteri asam laktat dihitung menggunakan metode Total Plate Count sedangkan aktivitas antioksidan diuji menggunakan metode DPPH. Uji penerimaan menggunakan metode uji hedonik.

Hasil : Tidak ada pengaruh penambahan ekstrak kayu manis dengan berbagai perlakuan terhadap total bakteri asam laktat. Yoghurt dengan penambahan 0,5\% ekstrak kayu manis memiliki aktivitas antioksidan tertinggi 77,33\%. Pada penerimaan, kontrol dan perlakuan berbeda pada aroma, rasa serta tekstur namun tidak berbeda pada warna.

Simpulan : Formulasi yoghurt herbal sinbiotik terbaik adalah yoghurt dengan penambahan 0,3\% ekstrak kayu manis yang memiliki total bakteri asam laktat sesuai $S N I \geq 10^{7} \mathrm{CFU} / \mathrm{ml}$, aktivitas antioksidan cukup tinggi 56,67\%, dan penerimaan yang cukup disukai.

Kata kunci : yoghurt herbal, inulin, karagenan, kulit kayu manis, aktivitas antioksidan, total bakteri asam laktat

\section{PENDAHULUAN}

Menurut kriteria National Cholesterol Education Program Adult Treatment Panel III (NCEP ATP III), seseorang dikatakan sindrom metabolik jika memiliki setidaknya tiga dari lima tanda: glukosa plasma puasa 110-125 mg/dL; lingkar pinggang > 40 inchi pada pria dan $>35$ inchi pada wanita; trigliserida $\geq 150 \mathrm{mg} / \mathrm{dL} ; \mathrm{HDL}<40 \mathrm{mg} / \mathrm{dL}$ pada pria dan $<50 \mathrm{mg} / \mathrm{dL}$ pada wanita; dan tekanan darah $\geq 130 / 85$ mmHg. ${ }^{1}$ Prevalensi sindrom metabolik dalam penelitian di beberapa negara beragam, pada pria yaitu $7,9-43,6 \%$ sedangkan pada wanita $7-56 \% .^{2}$ Pada tahun 2006 prevalensi sindrom metabolik di Indonesia sebesar 28,4\% dengan kriteria yang sering muncul pada pria adalah hipertensi dan obesitas sentral pada wanita. ${ }^{3}$

Terdapat banyak faktor risiko yang menyebabkan terjadinya sindrom metabolik, seperti obesitas, resistensi insulin, rasio lingkar pinggang terhadap lingkar panggul, hipertensi, interelasi glukosa-insulin-lemak, dislipidemia, genetik, fungsi endotelial, keadaan hiperkoagulabilitas, diet, stres kronis, dan aktivitas glukokortikoid. ${ }^{4,5,7}$ Faktor risiko tersebut termasuk masalah-masalah gizi yang dapat disebabkan oleh diet dari masing-masing individu. Namun harus ada diet khusus jika sudah 
berisiko atau bahkan menderita sindrom metabolik. Intervensi diet yang memperbaiki perubahan gaya hidup, berat badan, dislipidemia, serta tekanan darah dapat menjadi alternatif untuk menurunkan sindrom metabolik. Perubahan diet ini dapat meliputi carbohydrate-restricted diets $(\mathrm{CRD})^{8}$, diet rendah lemak $^{9}$, dan meningkatkan asupan buah dan sayur. ${ }^{10}$ Pola diet yang cenderung tinggi gandum olahan, daging olahan, makanan yang digoreng, minuman bersoda, serta daging merah meningkatkan $18 \%$ risiko sindrom metabolik, sedangkan asupan susu dan produk olahannya memiliki efek protektif sebesar $13 \% .{ }^{11}$ Mengonsumsi susu dan produk olahannya kurang lebih 3 porsi per hari dapat mengurangi marker dari sindrom metabolik karena kandungan kalsiumnya melalui jalur modulasi 1, 25hydroxyvitamin $\mathrm{D} .^{12}$

Diet dengan antioksidan dapat menurunkan kejadian sindrom metabolik. Ketidakseimbangan antara antioksidan dan prooksidan di dalam tubuh dapat menyebabkan terjadinya stres oksidatif. Meningkatnya stres oksidatif dapat menurunkan fungsi insulin dan menyebabkan terjadinya sindrom metabolik. ${ }^{13}$ Tanaman herbal kayu manis (Cinnamomum burmannii) memiliki beberapa flavonoid utama yang merupakan antioksidan yaitu cinnamic aldehyde, cinnamyl acetate dan eucalyptol ${ }^{14}$ serta memiliki euganol sebagai fenol utamanya. ${ }^{15}$ Kandungan total flavonoid kayu manis sebesar $2738.4 \mu \mathrm{g}$ QE/g sedangkan kadar fenolnya 943,7 $\mu \mathrm{g}$ /g dan menurut hasil uji aktivitas antioksidan melalui metode DPPH dalam $100 \mu \mathrm{g} / \mathrm{mL}$ memiliki aktivitas antioksidan 45,2\%. ${ }^{16}$ Antioksidan dalam kayu manis ini dapat membantu mengatasi stess oksidatif yang terjadi dalam tubuh. Pemberian $250 \mathrm{mg}$ kapsul ekstrak kayu manis pada orang dengan overweight dan obesitas sebanyak 2 kali per hari selama 12 minggu dapat menurunkan glukosa puasa dari $114 \pm$ 2,2 menjadi $102 \pm 4,3 \mathrm{mg} / \mathrm{dL} .{ }^{17}$ Penambahan esktrak kayu manis pada mentega sebelumnya telah dilakukan sebanyak 1\%,3\% dan 5\% dengan aktivitas antioksidan tertinggi $38.73 \pm 0.01 \%$ dan penerimaan panelis yang terbaik terdapat pada penambahan $3 \%{ }^{18}$

Formulasi yoghurt dengan penambahan inulin, karagenan serta herbal kayu manis dapat menjadi inovasi produk untuk menurunkan sindrom metabolik. Penambahan inulin sebagai prebiotik pada yoghurt akan memberikan efek sinbiotik yang baik pada sindrom metabolik, karena pemberian 30 gram inulin per hari selama 9 minggu dapat menurunkan $5.3 \pm 0.1 \%$ berat badan dan menurunkan $2.3 \pm 0.5 \%$ lebih signifikan dari kontrol setelah 18 minggu. ${ }^{19}$ Pada penelitian sebelumnya inulin dalam yoghurt ditambahkan sebanyak $4 \% .^{20,21}$ Suplementasi $250 \mathrm{mg}$ karagenan per hari dalam 20 hari terbukti dapat secara signifikan menurunkan $16,5 \%$ kadar kolesterol total dan 33,5\% kadar LDL-C. ${ }^{22}$ Penelitian sebelumnya telah menggunakan karagenan pada yoghurt stroberi dengan penambahan sebanyak $0,8 \%$ sebagai penambahan yang terbaik. ${ }^{23}$ Stevia akan digunakan dalam formulasi ini karena menurunkan tingkat insulin post prandial dan glukosa darah post prandial lebih baik dari aspartam dan sukrosa. ${ }^{24}$ Tikus betina yang diberikan stevia $1000 \mathrm{mg} / \mathrm{kg} /$ hari selama 12 minggu mengalami penurunan berat badan signifikan sebanyak $48.29 \%$. ${ }^{25}$ Efek tersebut dapat mengatur regulasi glukosa dalam tubuh dan tentu baik untuk penderita sindrom metabolik.

Yoghurt herbal sinbiotik dengan penambahan ekstrak kayu manis memiliki kandungan antimikroba yang dapat menghambat pertumbuhan Escherihia coli dan Staphylococcus aureus. ${ }^{26,27}$ Kandungan antimikroba ini berasal dari ekstrak etanol batang kayu manis ${ }^{27}$ dan bifidobakteria yang dihasilkan dalam proses fermentasi yoghurt. ${ }^{26}$ Kandungan antimikroba pada yoghurt dapat meningkatkan umur simpannya. Tujuan penelitian ini akan menganalisis pengaruh penambahan ekstrak kayu manis dan penambahan karagenan terhadap total bakteri asam laktat (BAL), aktivitas antioksidan, dan penerimaan produk yoghurt herbal sinbiotik dengan penambahan ekstrak kayu manis.

\section{METODE}

Penelitian dilakukan di Laboratorium Terpadu Universitas Diponegoro untuk pembuatan, uji total bakteri asam laktat serta uji aktivitas antioksidan yoghurt herbal sinbiotik dengan penambahan ekstrak kayu manis sedangkan uji penerimaannya dilakukan di Jurusan Ilmu Gizi Fakultas Kedokteran Universitas Diponegoro. Penelitian dilakukan pada bulan Juli - Oktober 2016.

Kayu manis berasal dari Pasar Bulu Semarang, susu sapi segar berasal dari Fakultas Peternakan dan Pertanian Universitas Diponegoro, karagenan berasal dari UKM Suket Segoro, stevia berasal dari bubuk stevia dengan salah satu merk dagang dan inulin dari PT DPO Indonesia. Bakteri Streptococcus thermophilus dan Lactobacillus bulgaricus didapatkan dari Laboratorium PAU Universitas Gadjah Mada.

Penelitian ini merupakan penelitian true experimental dengan rancangan acak lengkap satu faktor, yaitu penambahan ekstrak kayu manis $0 \%$; $0,1 \% ; 0,3 \%$; dan $0,5 \%$ pada yoghurt herbal sinbiotik. Penentuan jumlah ekstrak ini didapatkan dari hasil penelitian pendahulan. Analisis total bakteri asam laktat dan aktivitas antioksidan dilakukan dengan 3 ulangan, namun untuk uji penerimaan dilakukan tanpa pengulangan. Penambahan inulin pada penelitian ini berdasarkan penambahan inulin pada penelitian sebelumnya dengan produk jelly yoghurt 
sarikaya ${ }^{21}$. Penambahan stevia disesuaikan dengan standar European Food Safety Authority (EFSA) yaitu $4 \mathrm{mg} / \mathrm{kgBB}$ dengan asumsi berat badan $50 \mathrm{~kg}$ dan konsumsi $100 \mathrm{ml}$ yoghurt didapatkan formula stevia sebanyak $0,2 \%{ }^{28}$ sedangkan penambahan karagenan dan starter berdasarkan hasil penelitian pendahuluan. Ekstrak kayu manis yang digunakan diekstraksi menggunakan metode sokletasi selama 48 jam menggunakan pelarut etanol $70 \% .^{29}$

Pembuatan yoghurt herbal sinbiotik dengan penambahan kayu manis diawali dengan pasteurisasi susu pada suhu $75^{\circ} \mathrm{C}$ selama $15-30$ menit kemudian didinginkan hingga suhu $43-45^{\circ} \mathrm{C}$. Diambil sebagian susu untuk pembiakan starter Streptococcus thermophilus dan Lactobacillus bulgaricus selama 8 jam dengan suhu $37-43^{\circ} \mathrm{C}$, lakukan hingga mendapatkan starter sebanyak $10 \%$. Setelah itu ditambahkan starter $10 \%$, inulin $4 \%$ sebagai sumber prebiotik, dan stevia $0,2 \%$ sebagai pemanis yang aman bagi penderita diabetes ${ }^{25}$ pada sebagian susu yang sudah dipasteurisasi tadi. Kemudian diinkubasi selama 8-10 jam (pH 4) pada suhu $37-43^{\circ} \mathrm{C}$. Setelah diinnkubasi yoghurt ditambahkan karagenan 6\% dan ekstrak kayu manis kemudian dihomogenkan menggunakan blender.

Analisis total bakteri asam laktat dilakukan dengan metode Total Plate Count (TPC), sedangkan aktivitas antioksidan diuji menggunakan metode DPPH. ${ }^{18}$ Uji penerimaan dilakukan dengan metode uji hedonik kepada 30 panelis agak terlatih yang merupakan mahasiswa Program Studi Ilmu Gizi Fakultas Kedokteran Universitas Diponegoro menggunakan formulir uji penerimaan dengan 4 skala penerimaan sangat tidak suka $(1,00-1,45)$; tidak suka $(1,5-2,45)$; suka $(2,5-3,45)$ dan sangat suka $(3,50-4,00) \cdot{ }^{30}$ Uji penerimaan yang dilakukan dalam penelitian ini meliputi warna, aroma, rasa dan tekstur.

Seluruh data yang telah dikumpulkan diolah menggunakan software statistik. Sebelum diolah, data diuji normalitasnya menggunakan uji SaphiroWilk karena data bejumlah $\leq 50$. Pengaruh penambahan ekstrak kayu manis terhadap total bakteri asam laktat dianalisis menggunakan uji Kruskal-Wallis. Aktivitas antioksidan dianalisis dengan Uji One Way Anova dengan uji lanjut Tukey. Analisis penerimaan dilakukan menggunakan uji Friedman dengan uji lanjut Wilcoxon.

\section{HASIL}

\section{Total Bakteri Asam Laktat (BAL)}

Dari hasil analisis total bakteri asam laktat pada yoghurt herbal sinbiotik didapatkan $\mathrm{p}=0,264$, maka tidak ada pengaruh penambahan ekstrak kayu manis dengan berbagai perlakuan terhadap total bakteri asam laktat yoghurt. Meskipun demikian, semakin tinggi penambahan ekstrak kayu manis, jumlah total bakteri asam laktat yang ada semakin menurun.

Tabel 1. Hasil Analisis Total Bakteri Asam Laktat (BAL)

\begin{tabular}{cc}
\hline $\begin{array}{c}\text { Penambahan Ekstrak } \\
\text { Kayu Manis }\end{array}$ & $\begin{array}{c}\text { Total BAL (10 } \\
\text { CFU/ml) }\end{array}$ \\
\hline $0 \%$ & $1132,00 \pm 1531,14$ \\
$0,1 \%$ & $669,93 \pm 1151,87$ \\
$0,3 \%$ & $98,80 \pm 131,89$ \\
$0,5 \%$ & $83,46 \pm 73,49$ \\
\hline
\end{tabular}

\section{Aktivitas Antioksidan}

Penambahan ekstrak kayu manis berpengaruh $(\mathrm{p}=0,001)$ pada tingkat aktivitas antioksidan yoghurt herbal sinbiotik. Semakin tinggi penambahan esktrak kayu manis, semakin tinggi pula aktivitas antioksidannya. Dari hasil uji lanjut didapatkan perbedaan nilai aktivitas antioksidan antara seluruh perlakuan.

Tabel 2. Hasil Analisis Aktivitas Antioksidan

\begin{tabular}{cc}
\hline $\begin{array}{c}\text { Penambahan Ekstrak } \\
\text { Kayu Manis }\end{array}$ & $\begin{array}{c}\text { Aktivitas Antioksidan } \\
(\boldsymbol{\%})\end{array}$ \\
\hline $0 \%$ & $5,64 \pm 4,09^{\mathrm{d}}$ \\
$0,1 \%$ & $24,00 \pm 1,73^{\mathrm{c}}$ \\
$0,3 \%$ & $56,67 \pm 7,78^{\mathrm{b}}$ \\
$0,5 \%$ & $77,33 \pm 6,11^{\mathrm{a}}$ \\
\hline
\end{tabular}

Keterangan: Angka yang diikuti huruf superscript berbeda (a,b,c,d) menunjukkan beda nyata

\section{Penerimaan}

\section{Warna}

Yoghurt herbal sinbiotik yang ditambahkan maupun yang tidak ditambahkan ekstrak kayu manis seluruhnya disukai panelis dari segi penerimaan warna. Penambahan ekstrak kayu manis ini tidak menunjukkan adanya pengaruh yang nyata $(\mathrm{p}=0,333)$.

Tabel 3. Hasil Analisis Penerimaan terhadap Warna

\begin{tabular}{ccc}
\hline $\begin{array}{c}\text { Penambahan Ekstrak } \\
\text { Kayu Manis }\end{array}$ & Warna & Kriteria \\
\hline $0 \%$ & $3,07 \pm 0,907$ & Suka \\
$0,1 \%$ & $2,90 \pm 0,662$ & Suka \\
$0,3 \%$ & $2,87 \pm 0,571$ & Suka \\
$0,5 \%$ & $2,67 \pm 0,920$ & Suka \\
\hline \multicolumn{3}{c}{$\mathrm{p}=0,333$} \\
\hline
\end{tabular}

\section{Aroma}

Terdapat pengaruh penambahan ekstrak kayu manis terhadap tingkat kesukaan aroma yoghurt herbal sinbiotik $(\mathrm{p}=0,018)$. Penambahan ekstrak kayu manis sebanyak $0,1 \%$ dan $0,3 \%$ pada yoghurt disukai 
aromanya oleh panelis, namun tidak disukai pada penambahan ekstrak kayu manis $0,5 \%$.

Tabel 4. Hasil Analisis Penerimaan terhadap Aroma

\begin{tabular}{ccc}
\hline $\begin{array}{c}\text { Penambahan } \\
\text { Ekstrak Kayu Manis }\end{array}$ & Aroma & Kriteria \\
\hline $0 \%$ & $2,83 \pm 0,83^{\mathrm{a}}$ & Suka \\
$0,1 \%$ & $2,70 \pm 0,65^{\mathrm{b}}$ & Suka \\
$0,3 \%$ & $2,63 \pm 0,77^{\mathrm{c}}$ & Suka \\
$0,5 \%$ & $2,17 \pm 0,75^{\mathrm{d}}$ & Tidak Suka \\
\hline \multicolumn{3}{c}{} \\
\hline
\end{tabular}

Keterangan: Angka yang diikuti huruf superscript berbeda $(\mathrm{a}, \mathrm{b}, \mathrm{c}, \mathrm{d})$ menunjukkan beda nyata

\section{Rasa}

Panelis lebih menyukai rasa yoghurt herbal sinbiotik yang tidak ditambahkan ekstrak kayu manis daripada yang ditambahkan. Seluruh yoghurt yang ditambahkan ekstrak kayu manis berbagai persentase tidak disukai panelis. Namun jika dilihat dari analisis Friedman menunjukkan ada pengaruh yang signifikan antara penambahan ekstrak kayu manis dengan tingkat kesukaan rasa yoghurt herbal sinbiotik $(\mathrm{p}=0,000)$.

Tabel 5. Hasil Analisis Penerimaan terhadap Rasa

\begin{tabular}{ccc}
\hline $\begin{array}{c}\text { Penambahan Ekstrak } \\
\text { Kayu Manis }\end{array}$ & Rasa & Kriteria \\
\hline $0 \%$ & $2,60 \pm 0,77^{\mathrm{a}}$ & Suka \\
$0,1 \%$ & $2,43 \pm 0,77^{\mathrm{b}}$ & Tidak Suka \\
$0,3 \%$ & $2,10 \pm 0,71^{\mathrm{c}}$ & Tidak Suka \\
$0,5 \%$ & $1,17 \pm 0,77^{\mathrm{d}}$ & Tidak Suka \\
\hline \multicolumn{3}{c}{$\mathrm{p}=0,000$} \\
\hline
\end{tabular}

Keterangan: Angka yang diikuti huruf superscript berbeda (a,b,c,d) menunjukkan beda nyata

\section{Tekstur}

Analisis statistik menunjukkan terdapat pengaruh penambahan ekstrak kayu manis terhadap tingkat kesukaan tekstur yoghurt herbal sinbiotik $(\mathrm{p}=0,000)$. Panelis tidak menyukai tekstur yoghurt herbal sinbiotik dengan penambahan $0,5 \%$ ekstrak kayu manis, namun menyukai yoghurt dengan penambahan $0,1 \%$ dan $0,3 \%$ ekstrak kayu manis.

Tabel 6. Hasil Analisis Penerimaan terhadap Tekstur

\begin{tabular}{ccc}
\hline $\begin{array}{c}\text { Penambahan Ekstrak } \\
\text { Kayu Manis }\end{array}$ & Tekstur & Kriteria \\
\hline $0 \%$ & $3,13 \pm 0,68^{\mathrm{a}}$ & Suka \\
$0,1 \%$ & $2,97 \pm 0,56^{\mathrm{b}}$ & Suka \\
$0,3 \%$ & $2,83 \pm 0,53^{\mathrm{c}}$ & Suka \\
$0,5 \%$ & $2,43 \pm 0,77^{\mathrm{d}}$ & Tidak Suka \\
\hline & & $\mathrm{p}=0,000$
\end{tabular}

Keterangan: Angka yang diikuti huruf superscript berbeda $(\mathrm{a}, \mathrm{b}, \mathrm{c}, \mathrm{d})$ menunjukkan beda nyata

\section{PEMBAHASAN}

\section{Total Bakteri Asam Laktat}

Semakin tinggi penambahan ekstrak kayu manis pada yoghurt herbal sinbiotik berbanding terbalik dengan jumlah total bakteri asam laktat yang cenderung menurun. Meskipun demikian seluruh perlakuan memiliki jumlah bakteri asam laktat yang sesuai dengan batas ambang SNI untuk memberikan dampak pada kesehatan yaitu $10^{7} \mathrm{CFU} / \mathrm{ml} .^{31}$

Penurunan jumlah bakteri asam laktat pada yoghurt herbal sinbiotik ini disebabkan oleh antimikroba yang terdapat di dalamnya. Kayu manis mengandung komponen cinnamaldehyde yang bersifat antibakteri. Cinnamaldehyde sebanyak 0,2\% dapat menurunkan 3-log jumlah bakteri asam laktat. ${ }^{32}$ Ekstrak kayu manis dapat menghambat perkembangan bakteri dalam fermentasi yoghurt karena kandungan antibakterinya yang menghambat pertumbuhan bakteri. ${ }^{33}$

\section{Aktivitas Antioksidan}

Semakin banyak ekstrak kayu manis yang ditambahkan semakin tinggi pula aktivitas antioksidan yoghurt herbal sinbiotik. Yoghurt herbal sinbiotik memiliki aktivitas antioksidan tertinggi pada penambahan ekstrak kayu manis sebanyak $0,5 \%$. Kayu manis memiliki beberapa kandungan yang merupakan antioksidan yaitu cinnamaldehyde, cinnamyl acetate, eucalyptol ${ }^{14}$ dan euganol. ${ }^{15}$ Pada uji pendahuluan dalam 0,1 gram ekstrak kayu manis memiliki aktivitas antioksidan $67 \%$.

Yoghurt tanpa penambahan kayu manis masih memiliki aktivitas antioksidan karena selain kayu manis, komponen lain dari produk yoghurt herbal sinbiotik ini memiliki antioksidan pula. Stevia memiliki komponen polifenol yang memiliki aktivitas antioksidan 22,6\%. ${ }^{34}$ Karagenan memiliki antioksidan mencapai 33,38\% karena memiliki sulfat yang dapat menghambat radikal bebas. ${ }^{35}$ Inulin juga memiliki aktivitas antioksidan meskipun jumlahnya tidak sebanyak komponen lain yaitu $14 \%$ yang berasal dari kemampuan gugus hidroksida $(\mathrm{OH})$ dalam menangkap radikal bebas. ${ }^{36}$ Yoghurt yang sudah difermentasi memiliki peptida, gugus amin bebas dan asam lemak degan aktivitas antioksidan sebesar 52,44\%. Proses fermentasi ini meningkatkan aktivitas antioksidan dibandingkan dengan susu yang tidak terfermentasi. ${ }^{37}$

Penderita sindrom metabolik membutuhkan diet khusus dengan tinggi antioksidan karena tingginya $\mathrm{H}_{2} \mathrm{O}_{2}$ dalam tubuhnya. Tingginya konsentrasi $\mathrm{H}_{2} \mathrm{O}_{2}$ yang merupakan prooksidan dalam tubuh dapat menggantikan kerja insulin namun dalam mekanisme yang lebih rendah. Insulin yang sebagian fungsinya tergantikan oleh $\mathrm{H}_{2} \mathrm{O}_{2}$ lama kelamaan membuatnya bersifat resisten. Resistensi insulin ini dapat mengawali terjadinya kondisi sindrom 
metabolik. ${ }^{38} \mathrm{H}_{2} \mathrm{O}_{2}$ yang reaktif ini dapat dinetralisasi dengan antioksidan.

\section{Penerimaan \\ Warna}

Panelis menyukai seluruh yoghurt herbal sinbiotik baik yang ditambahkan ekstrak kayu manis maupun tidak. Penambahan ekstrak kayu manis pada yoghurt herbal sinbiotik tidak mempengaruhi warna produk. Hal ini disebabkan oleh ekstrak kayu manis yang berwarna coklat tidak mempengaruhi warna yoghurt yang tetap putih.

Aroma

Yoghurt herbal sinbiotik yang tidak ditambahkan ekstrak kayu manis dan yang ditambahkan kayu manis $(0,1 \%$ dan $0,3 \%)$ disukai oleh panelis namun pada penambahan ekstrak kayu manis $0,5 \%$ memiliki aroma yang tidak disukai oleh panelis. Hal ini disebabkan oleh cinnamaldehyde, cinnamic alkohol, eugenol yang merupakan senyawa aromatik yang terdapat dalam kayu manis yang menimbulkan aroma wangi dan tajam. ${ }^{39,40}$ Senyawa aromatik inilah yang menjadikan aroma kayu manis sangat tajam saat uji penerimaan.

Rasa

Seluruh yoghurt herbal sinbiotik yang ditambahkan ekstrak kayu manis cenderung tidak disukai oleh panelis dibandingkan dengan yoghurt herbal sinbiotik yang tidak ditambahkan kayu manis dalam segi rasa. Kayu manis memiliki kandungan coumarin dan cinnamaldehyde yang memberikan rasa hangat dan pedas yang kuat yang membuat tingkat kesukaannya menurun. ${ }^{41}$ Selain itu rasa asam yang kuat juga terasa akibat proses fermentasi, tidak ditambahkannya gula juga menjadi salah satu faktor yang membuat yoghurt terasa lebih asam.

\section{Tekstur}

Yoghurt herbal sinbiotik dengan penambahan ekstrak kayu manis sebanyak 0,5\% memiliki tekstur yang tidak disukai oleh panelis. Hal ini terjadi karena ekstrak kayu manis memiliki tektur berpasir yang mempengaruhi tekstur pada yoghurt herbal sinbiotik.

\section{Penentuan Produk Terbaik}

Meskipun total bakteri asam laktat menurun pada seluruh yoghurt sinbiotik yang ditambahkan ekstrak kayu manis, ketiganya tetap memiliki total bakteri asam laktat sesuai SNI yaitu $10^{7} \mathrm{CFU} / \mathrm{ml}^{31}$ Dari aktivitas antioksidan, yoghurt herbal sinbiotik dengan penambahan ekstrak kayu manis $0,5 \%$ yang memiliki kandungan aktivitas antioksidan tertinggi. Dari segi penerimaan warna seluruh yoghurt dengan penambahan ekstrak kayu manis disukai, namun tidak pada rasa. Tekstur dan aroma yoghurt herbal sinbiotik disukai panelis pada kadar penambahan $0,1 \%$ dan $0,3 \%$. Maka secara keseluruhan produk terbaik adalah yoghurt herbal sinbiotik dengan penambahan ekstrak kayu manis sebanyak $0,3 \%$.

\section{SIMPULAN}

Penambahan ekstrak kayu manis pada yoghurt herbal sinbiotik tidak mempengaruhi total bakteri asam laktat dan penerimaan dari segi warna, sedangkan pada aktivitas antioksidan serta penerimaan dari segi aroma, rasa dan tekstur terdapat pengaruh. Semakin tinggi penambahan ekstrak kayu manis, semakin tinggi aktivitas antioksidannya, namun menurun pada aroma, rasa dan tekstur produk. Yoghurt herbal sinbiotik dengan formulasi terbaik adalah pada yoghurt yang ditambahkan ekstrak 0,3\% yang memiliki total bakteri asam laktat sesuai SNI $\geq$ $10^{7} \mathrm{CFU} / \mathrm{ml}$, aktivitas antioksidan cukup tinggi $56,67 \%$, dan penerimaan yang cukup disukai.

\section{SARAN}

Ekstraksi herbal kayu manis sebaiknya dilakukan dengan pelarut air agar mudah larut dalam yoghurt herbal sinbiotik. Selain itu penambahan gula dengan jumlah yang sesuai untuk pasien dengan sindrom metabolik juga diperlukan agar tingkat kesukaan dalam segi rasa meningkat.

\section{UCAPAN TERIMAKASIH}

Penulis mengucapkan terimakasih atas didanainya penelitian ini oleh Riset Pengembangan dan Penerapan dengan dana PNBP Universitas Diponegoro tahun anggaran 2016. Penulis juga tidak lupa mengucapkan terimakasih kepada seluruh pembimbing dan penguji atas masukkan, kritik, dan saran atas penelitian ini. Penulis juga mengucapkan terimakasih kepada semua pihak yang telah mendukung terselesaikannya penelitian ini.

\section{DAFTAR PUSTAKA}

1. Miranda, P. J., DeFronzo, R. a, Califf, R. M. \& Guyton, J. R. Metabolic Syndrome: Definition, Pathophysiology, and Mechanisms. Am. Heart J. 149, 33-45 (2005).

2. Cameron, A. J., Shaw, J. E. \& Zimmet, P. Z. The metabolic syndrome: prevalence in worldwide populations. Endocrinol. Metab. Clin. North Am. 33, 351-75, table of contents (2004).

3. Soewondo, P., Purnamasari, D., Oemardi, M. \& Waspadji, S. Prevalence of Metabolic Syndrome Using NCEP / ATP III Criteria in Jakarta, Indonesia: The Jakarta Primary Noncommunicable Disease Risk Factors Surveillance 2006. Acta Med Indones-Indones J Intern Med 42, 199-203 (2006).

4. Standl, E. Aetiology and Consequences of The Metabolic Syndrome. Eur. Hear. J. Suppl. 7, 10- 


\section{3 (2005).}

5. Unwin, N. The Metabolic Syndrome. J. R. Soc. Med. 99, 457-462 (2006).

6. Braunschweig, C. L. et al. Obesity and Risk Factors for The Metabolic Syndrome Among Low- income, Urban, African American Schoolchildren: The Rule Rather than The Exception? Am. J. Clin. Nutr. 81, 970-975 (2005).

7. Kaur, J. A Comprehensive Review on Metabolic Syndrome. Cardiol. Res. Pract. 2014, 1-21 (2014).

8. Al-sarraj, T., Saadi, H., Calle, M. C., Volek, J. S. \& Fernandez, M. L. Carbohydrate Restriction , as a First-Line Dietary Intervention, Effectively Reduces Biomarkers of Metabolic Syndrome in Emirati Adults. J. Nutr. 1667-1676 (2009). doi:10.3945/jn.109.109603.Traditionally

9. Klemsdal, T. O., Holme, I., Nerland, H., Pedersen, T. R. \& Tonstad, S. Effects of A Low Glycemic Load Diet Versus A Low-fat Diet in Subjects with and without The Metabolic Syndrome. Nutr. Metab. Cardiovasc. Dis. 20, 195-201 (2010).

10. Esmaillzadeh, A. et al. Fruit and Vegetable Intakes, C-Reactive Protein , and The Metabolic Syndrome. Am. J. Clin. Nutr. 84, (2006).

11. Lutsey, P. L., Steffen, L. M. \& Stevens, J. Dietary Intake and The Development of The Metabolic Syndrome: The Atherosclerosis Risk in Communities study. Circulation 117, 754761 (2008).

12. Dugan, C. E. \& Fernandez, M. L. Effects of Dairy on Metabolic Syndrome Parameters : A Review. Yale J. Biol. Med. 87, 135-147 (2014).

13. Ford, E. S., Mokdad, A. H., Giles, W. H. \& Brown, D. W. The Metabolic Syndrome and Antioxidant Concentrations: Findings from The Third National Health and Nutrition Examination Survey. Diabetes 52, 2346-52 (2003).

14. Morais, S. M. De, Cavalcanti, E. S. B., Costa, S. M. O. \& Aguiar, L. A. Ação antioxidante de chás e condimentos de grande consumo no Brasil. Rev. Bras. Farmacogn. 19, 315-320 (2009).

15. Shen, Y., Jia, L., Honma, N., Hosono, T. \& Ariga, T. Beneficial Effects of Cinnamon on the Metabolic Syndrome, Inflammation, and Pain , and Mechanisms Underlying These Effects - A Review. J. pf Tradit. Coplementary Med. 2, 2732 (2011).

16. Prasad, K. N. et al. Flavonoid Contents and Antioxidant Activities from Cinnamomum Species. Innov. Food Sci. Emerg. Technol. 10, 627-632 (2009).

17. Roussel, A., Hininger, I., Benaraba, R.,
Ziegenfuss, T. N. \& Anderson, R. A. Antioxidant Effects of a Cinnamon Extract in People with Impaired Fasting Glucose That are Overweight or Obese. J. Am. Coll. Nutr. 28, 1621 (2009).

18. Vidanagamage, S. A., Pathiraje, P. M. H. D. \& Perera, O. D. A. N. Effects of Cinnamon (Cinnamomum Verum) Extract on Functional Properties of Butter. Procedia Food Sci. 6, 136142 (2016).

19. Guess, N. D. et al. A randomized controlled trial : the effect of inulin on weight management and ectopic fat in subjects with prediabetes. Nutr. Metab. (Lond). 1-10 (2015). doi:10.1186/s12986-015-0033-2

20. Pratiwi, R. U. \& Rustanti, N. Kadar Fenol Total, Aktivitas Antioksidan dan Tingkat Kesukaan Minuman Fungsional Jelly Yoghurt Srikaya dengan Penambahan Karagenan. J. Nutr. Coll. 4, 329-334 (2015).

21. Harjantini, U. \& Rustanti, N. Total Bakteri Asam Laktat, $\mathrm{pH}$, dan Kadar Serat Minuman Fungsional Jelly Yoghurt Srikaya dengan Penambahan Karagenan. J. Nutr. Coll. 4, 514519 (2015).

22. Sokolova, E. V. et al. Effect of carrageenan food supplement on patients with cardiovascular disease results in normalization of lipid profile and moderate modulation of immunity system markers. PharmaNutrition 2, 33-37 (2014).

23. Hapsari, A. P., Suptijah, P. \& Trilaksani, W. Formulasi dan Karakterisasi Minuman Fungsional Fruity Jelly Yoghurt berbasis Kappa Karaginan sebagai Sumber Serat Pangan. (2011).

24. Anton, S. D. et al. Effects of Stevia, Aspartame, and Sucrose on Food Intake, Satiety, and Postprandial Glucose and Insulin Levels. Appetite 55, 37-43 (2010).

25. Abo Elnaga, N. I. E., Massoud, M. I., Yousef, M. I. \& Mohamed, H. H. a. Effect of stevia sweetener consumption as non-caloric sweetening on body weight gain and biochemical's parameters in overweight female rats. Ann. Agric. Sci. 1-9 (2016). doi:10.1016/j.aoas.2015.11.008

26. IA, A. E.-G., EM, E.-S., HM, E.-Z., SA, H. \& FA, S. Antibacterial Activity of Probiotic Yoghurt and Soy-Yoghurt against Escherichia coli and Staphylococcus aureus. Nutr. Food Sci. 4, 1-6 (2014).

27. Angelica, N. Aktivitas Antibakteri Ekstrak Etanol Daun dan Kulit Batang Kayu Manis (Cinnamomum burmanii (Nees \& Th. Nees)) terhadap Eschericia coli dan Staphyloccus aureus. J. Ilm. Mhs. Univ. Surabaya 2, 1-8 
(2013).

28. Beneford, D., M, D. \& J, S. in Safety evaluation of certain food additives, WHO food additive series 117-114 (2006).

29. Yang, C.-H., Li, R.-X. \& Chuang, L.-Y. Antioxidant Activity of Various Parts of Cinnamomum cassia Extracted with Different Extraction Methods. Molecules 17, 7294-7304 (2012).

30. Ayustaningwarno, F. Teknologi Pangan, Teori Praktis dan Aplikasi. (Graha Ilmu, 2014).

31. Nasional, B. S. SNI Yoghurt. (2009). Available at:

sisni.bsn.go.id/index.php?sni_main/sni/detail_s ni/3373. (Accessed: 29th November 2016)

32. Gann, L. D. Antimicrobial Activity of Essential Oils and Their Components Against Lactic Acid Bacteria. (University of Tennessee Knoxville, 2013).

33. Choi, Y. J., Jin, H. Y., Yang, H. S., Lee, S. C. \& Huh, C. K. Quality and storage characteristics of yogurt containing Lacobacillus sakei ALI033 and cinnamon ethanol extract. J. Anim. Sci. Technol. 1-7 (2016). doi:10.1186/s40781-0160098-0

34. Antioxidant Activity of Stevia ( Stevia rebaudiana L .) Leaf Powder and A Commercial Stevioside Powder. J. Foof Pharm. Sci. 2, 32-38 (2014).
35. Cristiane, M. et al. Antioxidant Activities of Sulfated Polysaccharides from Brown and Red Seaweeds. J Appl Phycol 19, 153-160 (2007).

36. Ren, J., Liu, J., Dong, F. \& Guo, Z. Highly efficient synthesis and antioxidant activity of $\mathrm{O}$ ( aminoethyl ) inulin. Carbohydr. Polym. 83, 1240-1244 (2011).

37. Gjorgievski, N., Tomovska, J., Dimitrovska, G., Makarijoski, B. \& Shariati, M. A. Determination of The Antioxidant Activity in Yogurt. J. Hyg. Eng. Des. 88-92 (2013).

38. Bonomini, F., Rodella, L. F. \& Rezzani, R. Metabolic Syndrome, Aging and Involvement of Oxidative Stress. Aging Dis. 6, 109 (2015).

39. Bakkali, F. \& Idaomar, M. Biological effects of essential oils - A review. Food Chem. Toxicol. 46, 446-475 (2008).

40. Barceloux, D. G. Cinnamon (Cinnamomum Species). Disease-a-Month 55, 327-335 (2009).

41. Wang, Y. H., Avula, B., Nanayakkara, N. P. D., Zhao, J. \& Khan, I. A. Cassia cinnamon as a source of coumarin in cinnamon-flavored food and food SUPPL.ements in the United States. $J$. Agric. Food Chem. 61, 4470-4476 (2013). 